\title{
PENERAPAN ORNAMEN MOTIF GORGA PADA HIASAN DINDING
}

\author{
Rani Hermita ${ }^{1}$, Noprita Elisabeth Sianturi ${ }^{2}$ \\ Universitas Potensi Utama Fakultas Seni dan Desain Program Studi Desain Interior ${ }^{1,2}$ \\ ranihermita88@gmail.com ${ }^{1}$,novryelisa@gmail.com ${ }^{2}$
}

\begin{abstract}
ABSTRAK
Penelitian ini bertujuan untuk menciptakan dan menghasilkan kreasi baru terhadap beberapa ragam hias dalam pembuatan dan penerapan motif Gorga yang diaplikasi dalam bentuk hiasan dinding, namun dalam pembuatan hiasan dinding dengan menggunakan motif Gorga tidak menghilangkan bentuk aslinya. Ornamen Gorga biasanya banyak terdapat pada rumah adat batak toba yang diletakkan pada bagian atas plafon khusus pada bagian depan diatas pintu atau dinding. Seiring berkembangnya beberapa trend mode terhadap pengembangan unsur budaya maka ornamen Gorga mulai diaplikasikan pada produk kriya rumah tangga khususnya pada hiasan dinding. Pengaplikasian produk kriya hiasan dinding Gorga dibuat berdasarkan beberapa konsep dan pertembingan yang telah matang, diantaranya adalah dimulai dari menetukan topik atau ide gagasan, persiapaan bahan peralatan serta perlengkapan yang menunjang dalam pembuatan hiasan dinding, membuat sketsa gambar yang diambil dari motif Gorga, pembuatan hiasan dinding, dan yang terakhir adalah finishing. Kegiatan ini dilakukan dengan menggunakan metode wawancara, diskusi dan Tanya jawab tentang hiasan dinding Gorga, metode praktek langsung terhadap pembuatan hiasan dinding dan melihat proses pembuatan hiasan dinding Gorga.
\end{abstract}

KataKunci: Motif Gorga, Hiasan Dinding

\begin{abstract}
This research aims to create and produce new creations of several kinds of decorations in the manufacture and application of Gorga motifs which are applied in the form of wall hangings, however in making wall hangings using the Gorga motif does not eliminate the original form. Gorga ornaments are usually found in traditional Batak Toba houses that are placed on the top of a special ceiling at the front above the door or wall. Along with the development of several fashion trends towards the development of cultural elements, Gorga ornaments began to be applied to household craft products, especially in wall decoration. The application of Gorga wall decoration craft products is made based on several mature concepts and discussions, including starting from determining topics or ideas, preparing materials for tools and equipment that support the making of wall hangings, sketching pictures taken from Gorga motifs, making wall hangings., and the last one is finishing. This activity is carried out by using the interview method, discussion and question and answer about Gorga wall decoration, direct practice method for making wall decorations and seeing the process of making Gorga wall decorations.
\end{abstract}

Keywords: Gorga Motif, Wall Decoration

\section{PENDAHULUAN}

Seiring perkembangan zaman, melalui bentuk kreatifitas maka penciptaan ragam hias gorga diaplikasikan sebagai hiasan dinding yang dari bahan kayu yang dipahat 
untuk interior ruang. Hiasan dinding tersebut dibuat dengan berbagai macam bentuk. Bentuk hiasan dinding tersebut bertemakan Gorga. Ragam hias Gorga mempunyai arti bagi masyarakat batak yang mempunyai kaitan erat dengan aktivitas-aktivitas ritual atau digunakan dalam pembuatan horoscope seseorang atau sekeluarga. Ornamen atau ragam hias merupakan salah satu warisan sejarah bangsa Indonesia yang dimana hampir diseluruh suku yang ada di Indonesia memiliki berbagai macam jenis ornamen yang mencerminkan etnik masing- masing daerah di Indonesia. Ornamen Batak Toba salah satu contohnya yang merupakan salah satu diantara sekian banyak ornamen yang ada dipenjuru negara Indonesia ini. Ornamen Batak Toba bisa kita jumpai di provinsi Sumatera Utara tepatnya di Kabupaten Tobasa, Kabupaten Samosir, Kabupaten Humbang Hasundutan dan Kabupaten Taput. Suku Batak Toba sendiri selalu menerapkan ornamen Batak Toba sebagai hiasan ataupun sebagai identitas pada bangunan penting bagi suku Batak Toba, contohnya pada bangunan rumah adat dan bangunan Tambak Nabolon (pemakaman besar) dengan seiring perkembangan zaman banyak masyarakat yang mulai mengambil motif Gorga yang dijadikan sebagai motif karya seni, salah satu karya seni yang mulai trend dari motif Gorga adalah motif baju batik Gorga dan hiasan dinding 5 .

Dalam pembuatannya hiasan dinding diambil dari ornamen Gorga, untuk itu jika ingin memberikan hiasan pada rumah kita seharusnya mengetahui kondisi atau kebutuhan dalam rumah, sehingga akan menjadikan rumah indah. Dalam memilih hiasan ada banyak yang harus diperhatikan untuk dapat menjadikan rumah kita menarik, yang paling penting harus mengetahui beberapa hal untuk membuat rumah menjadi menarik contohnya mengetahui tipe atau gaya rumah yang akan kita beri hiasan, mengetahui warna dinding rumah sehingga dapat memberikan warna hiasan yang selaras dan ukuran yang dibutuhkan dalam rumah yang akan diberi hiasan dengan tersebut akan menjadi harmonis antara hiasan dan konsep dalam rumah. Dalam kesempatan ini saya akan memberikan contoh hiasan dinding yang dibuat dengan mengambil ornamen Gorga sebagai hiasan dinding, karena pada sekarang ini ornamen Gorga tidak hanya digunakan pada rumah adat batak toba saja tetapi sudah mulai berkembang menjadi trend masa kini yang sudah dikembangkan menjadi motif baju batik dan hiasan dinding rumah.

\section{STUDI LITERATUR}

Inspirasi membuat hiasan dinding dari motif ornamen Gorga:

II.1. Sebagai bahan refensi pertama inspirasi membuat hiasan dinding dari motif Gorga meninjau penelitian karya dari I Wayan Sutarman jurusan Teknik Industri. Rumusan masalah beserta pemaparan yang telah dilakukan pada bagian latar belakang masalah, kemudian bagaimana mengolah sisa potongan atau bilahan kayu yang tidak berguna dapat dibuat berupa furniture dan art work sebagai hiasan interior ruangan ${ }^{8}$.

II.2. Sebagai bahan refensi kedua inspirasi membuat hiasan dinding dari motif ornament Gorga meninjau penelitian karya dari Herman Susanto pendidikan seni rupa Universitas Negeri Yogyakarta. Rumusan masalah beserta pemaparan yang telah dilakukan pada bagian latar belakang masalah, kemudian bagaimana pemanfaatan limbah kayu sebagai bahan penciptaan jam lampu dinding dengan motif hias klasik jawa dan bali ${ }^{9}$. 
II.3. Sebagai bahan refensi ketiga inspirasi membuat hiasan dinding dari motif ornament Gorga meninjau penelitian karya dari Suharto dan Dwi Retno Sri Ambarwati staf pengajar FBS UNY Yogyakarta. Rumusan masalah beserta pemaparan yang telah dilakukan pada bagian latar belakang masalah, kemudian bagaimana pemanfaatan kelapa (batang, tapas, lidi, mancung, sabut, dan tempurung) sebagai bahan baku kerajinan ${ }^{7}$.

II.4. Sebagai bahan refensi keempat inspirasi membuat hiasan dinding dari motif ornamen Gorga meninjau penelitian karya dari Tulus Pranto Siburian mahasiswa Jurusan Seni Murni Fakultas Seni Rupa Institut Seni Indonesia Yogyakarta. Rumusan masalah beserta pemaparan yang telah dilakukan pada bagian latar belakang masalah, kemudian bagaimana ornamen gorga digunakan sebagai inpirasi membuat suatu karya seni ${ }^{6}$.

\section{PEMBAHASAN}

\section{A. Hiasan Dinding}

Hiasan dinding merupakan bagian interior yang berada di dalam rumah yang akan menjadikan rumah tampak lebih indah dan menarik, selain itu hiasan dinding juga akan menjadikan ruangan tampak nyaman dan menyenangkan, untuk itu dalam pengunaannya dan pemberian hiasan dinding ini sangat penting agar keadaan rumah tetap menarik dan memberikan kesan nyaman. Rumah yang nyaman tentu saja sangat penting karena dengan rumah yang menarik dan nyaman akan membuat kita semakin betah untuk tinggal dirumah sehingga akan memberikan manfaat yang baik untuk para penghuninya ${ }^{1}$.

Karena, rumah kadang menjadi salah satu pilihan yang tepat untuk kita bisa beristirahat dan mendapatkan kenyaman setelah melakukan aktivitas kerja seharian diluar rumah, untuk itu keadaan rumah harus selalu membuat kita nyaman dan bahkan yang paling penting membuat istirahat kita menjadi nyaman dan berkualitas, dengan begitu pekerjaan kita diluar rumah akan maksimal. Selain itu hiasan dinding juga banyak memiliki manfaat lain, terdapat beberapa manfaat berikut beberapa manfaat hiasan dinding dengan bentuk kaligrafi, hiasan ini tidak hanya memiliki bentuk dan kreasi yang indah dan menarik saja akan tetapi juga memiliki makna yang baik karena dalam hiasan kaligrafi ini merupakan doa yang baik. Begitu juga hiasan dinding yang dibuat dengan memberikan lampu, tentu selain memberikan keindahan dalam rumah juga memberikan penerangan yang unik dan menarik untuk ruangan dalam rumah, mungkin itu beberapa manfaat yang kita bisa dapatkan dalam memberikan hiasan dinding atau interior rumah yang indah dan menarik $^{2}$.

\section{Penting Dalam Memilih Bahan Berkualitas Dalam Hiasan Dinding}

Dalam hiasan dinding ini bahan merupakan hal yang utama dan penting untuk diperhatikan karena dengan bahan yang baik bukan hanya memberikan keindahan dalam hiasan saja melainkan juga akan menjadikan kualitas dari hiasan tersebut menjadi bertambah, dari sini kita bisa lihat bahwa bahan ini akan sangat mempengaruhi menariknya hiasan dan juga kualitas dari hiasan tersebut. Memilih bahan yang berkualitas ada beberapa cara yang pertama kita mengetahui kualitas atau ketahanan dari jenis bahan tersebut karena dalam 
kesempatan ini penulis menggunakan bahan kayu dalam pembuatan hiasan dinding, ketika kita menggunakan bahan kayu untuk pembuatan interior atau hiasan dalam rumah tentu harus memilih bahan yang baik dan berkualitas seperti kekuatan kayu, serat kayu, kekerasan kayu dan juga umur kamu yang digunakan. Yang jelas ketika kita memilih bahan kayu harus kayu yang tidak cacat seperti pecah, banyak mata kayu, retak, kayu masih muda dan beberapa cacat dan kekurangan lainnya yang akan menjadikan bahan tersebut kurang berkualitas.

\section{Pemilihan Bentuk Hiasan Yang Cocok Untuk Konsep Rumah}

Pemilihan bentuk ini sangat penting karena dengan pemilihan bentuk yang sesuai dengan konsep dan bentuk dalam rumah atau satu konsep dengan desain rumah tentu akan menjadikan ruangan rumah tersebut menjadi lebih indah dan menarik, seperti rumah memiliki gaya atau desain sama juga dengan hiasan dinding untuk menyesuaikan dengan bentuk rumah tentu juga memiliki bentuk dan gaya yang bisa disesuaikan dengan konsep rumah yang kita miliki. Beberapa konsep dalam rumah yang sering kita temukan seperti bentuk klasik, minimalis, modern dan kontemporer beberapa gaya ini tentu sudah sangat banyak kita temukan dalam lingkungan kita, kadang hanya kita tidak menyadari akan bentuk dan konsep tersebut sehingga menjadikan kita kurang paham dan mengetahui hal itu.

\section{Beberapa Pilihan Hiasan Dinding Dari Ormen Gorga}

Hiasan dinding memiliki beberapa bentuk dan kreasi, bahkan bahan yang digunakan dalam pembuatan hiasan ini saja sangat banyak akan tetapi disini tidak akan membahas itu, yang jelas setiap hiasan dinding ini memiliki bentuk dan karakter masing-masing untuk itu dalam kesempatan ini penulis akan memberikan beberapa hiasan dinding yang dibuat diambil dari motif Gorga. Pertama hiasan dinding dibuat mengambil dari ornamen Gorga, hiasan dinding ini dibuat dari bahan kayu yang akan disesuaikan dengan keadaan interior ruangan, yang menjadikan ruangan lebih berwarna.

\section{B. Ornamen}

Ornamen berasal dari bahasa latin ornare, yang mempunyai arti menghiasi. Ornamen merupakan komponen produk seni yang ditambahkan atau sengaja dibuat untuk tujuan sebagai hiasan. Bedasarkan pengertian tersebut, ornamen adalah penerapan hiasan pada suatu produk. Bentuk-bentuk hiasan yang menjadi ornamen tersebut fungsi utamannya adalah untuk memperindah benda produk atau barang yang dihias." Perkembangan ornamen Nusantara menunjuk pada bermacam bentuk ornamen yang tersebar di berbagai wilayah tanah air, pada umumnya bersifat tradisional yang pada setiap daerah memiliki khas dan keanekaragaman masing-masing, Karena itu ornamen Nusantara memiliki ciri-ciri daerahsesuai dengan cita rasa masyarakat setempat. Kehadiran sebuah ornamen tidak semata sebagai pengisi bagian kosong dan tanpa arti, seperti karya-karya ornamen masa lalu. Bermacam bentuk ornamen sesungguhnya memiliki fungsi, yaitu fungsi murni estetis, fungsi simbolis, fungsi teknik konstruktif ${ }^{4}$.

Pewarnaan yang digunakan pada motif gorga pada dasarnya hanya menggunakan tiga warna yaitu warna merah, warna putih dan warna hitam saja sebagai ciri khas motif itu sendiri. Untuk melihat motif gorga kita bisa melihatnya di Parsantian Parmalim pada 
umumnya telah menerapkan Ornamen motif gorga. Penerepan ornamen gorga pada Bale Parsantin Medan kemungkinan berbeda dengan penerapan pada bangunan lain di suku suku Batak Toba. Misalnya pada rumah adat, museum, kantor pemerintahan. Itu dipengaruhi dari perbedaan arsitektur bangunannya dan makna yang terkandung dalam setiap ornamen yang diterapkan. Contohnya pewarnaan pada bangunan bale Parsantian Medan ada penambahan warna yaitu warna kuning pada gorga ipon- ipon, dan gorga siga- singa yang berjumlah empat buah ${ }^{3}$.

\section{Fungsi Ornamen}

Fungsi simbolis ornamen pada umumnya dijumpai pada benda-benda upacara atau benda-benda pustaka yang bersifat keagamaan dan kepercayaan, menyertai nilai estetisnya. Misalnya ornamen yang menggunakan motif kala, cicak, biawak, naga, burung atau garuda, pada karya-karya masa lalu berfungsi simbolis. Bebagai bentuk ornamen diterapkan pada produk-produk dengan bermacam-macam cara. Sebagian dengan cara digambar atau dilukis, dibatik, sebagian lainnya ditoreh atau diukir, ada pula yang dengan cara ditempel, dianyam, ditenun. Dengan demikian ornamen diterapkan dalam lingkup yang luas dengan teknik yang bermacam-macam, meliputi ornamen pada anyaman dan tekstil, busana dan perhiasan, barang-barang kerajinan yang terbuat dari kayu, bambu, tulang dan logam serta peralatan lain, bahkan sampai pada arsitektur.

\section{Macam-Macam Ornamen Gorga}

Dilihat dari ornamen dan gambar-gambarnya dapat pula Gorga itu mempunyai namanamanya tersendiri yaitu ${ }^{10}$ :

a. Gorga Ipon-Ipon: terdapat dibahagian tepi dari Gorga, ipon-ipon dalam Bahasa Indonesia adalah gigi. Manusia tanpa gigi sangat kurang menarik, begitulah ukiran Batak, tanpa adanya ipon-ipon sangat kurang keindahan dan keharmonisannya. Ipon-ipon ada beraneka ragam, tergantung dari kemampuan para pengukir untuk menciptakannya. Biasanya Gorga ipon-ipon ini lebarnya antara dua sampai tiga sentimeter dipinggir papan dengan kata lain sebagai hiasan tepi yang cukup menarik.

b. Gorga Sitompi: Sitompi berasal dari kata tompi, salah satu perkakas Petani yang disangkutkan dileher kerbau pada waktu membajak sawah. Gorga Sitompi termasuk jenis yang indah di dalam kumpulan Gorga Batak. Disamping keindahannya, kemungkinan sipemilik rumah sengaja memesankannya kepada tukang Uhir (Pande) mengingat akan jasa alat tersebut (Tompi) itu kepada kerbau dan kepada manusia.

c. Gorga Simataniari (Matahari): Gorga yang menggambarkan matahari, terdapat disudut kiri dan kanan rumah. Gorga ini diperbuat tukang ukir (Pande) mengingat jasa matahari yang menerangi dunia ini, karena matahari juga termasuk sumber segala kehidupan, tanpa matahari takkan ada yang dapat hidup.

d. Gorga Desa Naualu (Delapan Penjuru Mata Angin): Gorga ini menggambarkan gambar mata angin yang ditambah hiasan-hiasannya. Orang Batak dahulu sudah mengetahui atau kenal dengan mata angin. Mata angin ini pun sudah mempunyai kaitan-kaitan erat dengan aktivitas-aktivitas ritual ataupun digunakan di dalam pembuatan horoscope seseorang atau sekeluarga. Sebagai pencerminan perasaan akan pentingnya mata angina pada suku Batak maka diperbuatlah dan diwujudkan dalam bentuk Gorga. 
e. Gorga Si Marogungogung (Gong): Pada zaman dahulu Ogung merupakan sesuatu benda yang sangat berharga. Ogung tidak ada dibuat di dalam negeri, kabarnya Ogung didatangkan dari India. Sedangkan pemakaiannya sangat diperlukan pada pesta-pesta adat dan bahkan kepada pemakaian pada upacara-upacara ritual, seperti untuk mengadakan Gondang Malim (Upacara kesucian). Dengan memiliki seperangkat Ogung pertanda bahwa keluarga tersebut merupakan keluarga terpandang. Sebagai kenangan akan kebesaran dan nilai Ogung itu sebagai gambaran atau keadaan pemilik rumah maka dibuatlah Gorga Marogung-ogung.

f. Gorga Singa-Singa: Dengan mendengar ataupun membaca perkataan Singa maka akan terlintas dalam hati dan pikiran kita akan perkataan: Raja Hutan, kuat, jago, kokoh, mampu, berwibawa. Tidak semua orang dapat mendirikan rumah Gorga disebabkan oleh berbagai faktor termasuk factor social ekonomi dan lain-lain. Orang yang mampu mendirikan rumah Gorga Batak jelaslah orang yang mampu dan berwibawa di kampungnya. Itulah sebabnya Gorga Singa dicantumkan di dalam kumpulan Gorga Batak

g. Gorga Jorgom: Ada juga orang menyebutnya Gorga Jorgom atau ada pula menyebutnya Gorga Ulu Singa. Biasa ditempatkan di atas pintu masuk ke rumah, bentuknya mirip binatang dan manusia.

h. Gorga Ulu Paung: Ulu Paung terdapat di puncak rumah Gorga Batak. Tanpa Ulu Paung rumah Gorga Batak menjadi kurang gagah. Pada zaman dahulu Ulu Paung dibekali (isi) dengan kekuatan metafisik bersifat gaib. Disamping sebagai memperindah rumah, Ulu Paung juga berfungsi untuk melawan begu ladang (setan) yang datang dari luar kampung. Zaman dahulu orang Batak sering mendapat serangan kekuatan hitam dari luar rumah untuk membuat perselisihan di dalam rumah (keluarga) sehingga tidak akur antara suami dan isteri. Atau membuat penghuni rumah susah tidur atau rasa takut juga sakit fisik dan berbagai macam ketidak harmonisan.

\section{METODE PENCIPTAAN}

Pada inspirasi membuat hiasan dinding diambil dari ornamen gorga, dari berbagai macam-macam bentuk ornamen gorga, penulis mengambil motif ornamen gorga singasinga sebagai pembuatan hiasan dinding. Metode yang digunakan dalam pembuatan hiasan dinding menggunakan beberapa metode diantaranya:

\section{Metode Pengumpulan data}

Dalam inpirasi membuat hiasan dinding dari ornamen gorga terdapat beberapa metode pengumpulan data dalam penelitian ini yaitu menggunakan metode kualitatif, yaitu metode perancangan yang berbasis riset, data yang dikumpulkan untuk membuat hiasan dinding dari ornamen gorga. Data yang dikumpulkan dalam penelitian ini terbagi menjadi dua yaitu data primer dan data sekunder:

a. Data primer

Adapun data primer yang penulis peroleh merupakan hasil pengamatan di lapangan yaitu sebagai berikut:

1. Bagaimana pembuatan hiasan dinding dari motif ornamen gorga.

2. Tidak terlalu sulit dalam pembuatan hiasan dinding dari motif ornamen gorga. 
3. Semakin berkembang motif gorga yang dijadikan sebagai trend busana atau untuk pelengkap interior ruangan.

\section{b. Data Sekunder}

Dalam inpirasi membuat hiasan dinding dari motif ornemen gorga juga diperlukan data sekunder yaitu data yang didapat dari keterangan dan informasi, dari karya-karya tulis yang berkaitan dengan pembuatan hiasan dinding dari ornamen gorga. Data sekunder ini digunakan untuk memperkuat data-data primer yang telah penulis dapatkan, data sekunder ini mudah didapat dan bermanfaat guna perumusan masalah.

\section{Metode Analisa Data}

Dalam inpirasi membuat hiasan dinding dari kayu alami tentunya diperlukan metode analisis atau langkah-langkah dalam riset dan proses kreatifitas, berikut adalah langkahlangkah dalam inpirasi membuat hiasan dinding dari kayi alami.

\section{a. Persiapan}

Proses pembuatan hiasan dinding dari motif ornemen gorga dilakukan persiapan berupa pengamatan mulai dari pengumpulan data yang dilakukan seperti observasi, dokumentasi, wawancara dan studi pustaka serta studi visual dengan cara melakukan pengamatan langsung pada pengerajin bagaimana cara pembuatan hiasan dinding dari motif gorga mulai dari membuat pola di atas kertas kemudian di gambar di atas kayu sampai dengan proses pemahatan hingga tahap terakhir yaitu menjadi hiasan dinding. Data yang didapat dari kegiatan di atas dijadikan pedoman dalam menggarap karya. Pada proses pembuatan hiasan dinding dari motif ornemen gorga.

\section{b. Studi Pustaka.}

Pada pembuatan hiasan dinding dari ornamen gorga dilakukan studi pustaka dalam Desain Komunikasi Visual guna menentukan berbagai sumber yang berkaitan dengan objek penciptaan yakni menelusuri data berupa artikel, video, buku, laporan penciptaan ataupun tulisan yang berkaitan dengan objek, sebagai referensi guna memperluas wawasan yang didapatkan.

Observasi suatu cara dalam pengumpulan data untuk penelitian, penulis mengumpulkan data dengan mengamati secara langsung pada kajian atau proses yang terjadi dilapangan. Observasi dilakukan pada bahan maket yang akan digunakan dan alat-alat.

\section{Teknik Analisa Data}

Analisis membuat hiasan dinding dari ornamen gorga ini menggunakan metode analisa $5 \mathrm{~W}+1 \mathrm{H}$ hal ini penting metode analisa data ini untuk menjawab pemecahan masalah dalam proses pembuatan hiasan dinding dari bahan ornamen gorga.

1. $5 \mathrm{~W}+1 \mathrm{H}$ :

a. What, apa yang akan dibuat? Rancangan yang akan dibuat yaitu membuat hiasan dinding dari ornamen gorga sebagai sumber ide gagasan.

b. Where, dimana akan diaplikasikan atau diterapkan? Analisis membuat hiasan dinding dari ornamen gorga nantinya akan diaplikasikan kedalam rancangan kebutuhan pembuatan hiasan dinding.

c. Who, Siapa target sasaran? Pada analisis membuat hiasan dinding dari ornamen gorga menjadi target sasaran adalah seluruh masyarakat umum. 
d. When, kapan dimulai? Pada analisis pembuatan hiasan dinding dari ornamen gorga dimulai sejak sekarang dan selanjutnya.

e. Why, mengapa diciptakan? Mempermudah masyarakat untuk membuat kreatifitas dari ornamen gorga di rumah sendiri.

f. How, bagaimana pembuatan hiasan dinding dari ornamen gorga tersebut? Dapat memilih dan menerapkan sendiri beberapa motif gorga yang diinginkan atau sesuai dengan kebutuhan dalam pembuatan hiasan dinding.

\section{Kajian Konsep}

Setelah mandapatkan data-data dari hasil analisa akan digunakan untuk merancang konsep perancangan. Hasil analisa data yang didapat digambarkan pada konsep perancangan yang lebih jelas. Konsep yang digunakan dalam analisis pembuatan hiasan dinding dari ornamen gorga konsep terdiri dari dua yaitu, konsep visual dan konsep verbal. Konsep ini akan digunakan pada tahapan perancangan mulai dari pemilihan motif dari ornamen gorga, pemahatan sampai menjadi hiasan dinding.

\section{Visualisasi Perancangan}

Setelah malakukan kajian konsep perancangan tahapan selanjutnya adalah visualisasi perancangan. Visualisasi perancangan terdiri dari bentuk-bentuk awal dari setiap pembuatan hiasan dinding. Tahapan ini merupakan akhir dari perancangan yang menghasilkan rancangan final.

\section{Bahan dan Alat Yang Di Gunakan}

- Kayu (Papan)

- Kikir

- Pahat

- Kertas

- Gergaji

- Kertas Pasir

- Penggaris

- Pensil

- Cat Minyak

- kuas

- Cat Pengkilat Kayu

\section{PEMBAHASAN}

\section{Proses Pembuatan Hiasan Dinding}

1. Terlebih dahulu buat pola gambar motif gorga singa-singa di atas kerta.

2. Kemudian gambar tersebut di cetak di atas kayu dan gambar menggunakan pensil.

3. Setelah gambar selesai di atas kayu, di pahat menggunakan alat pahat mengikuti pola yang sudah di gambar di atas kayu.

4. Kemudian potong kayu sesuai pahatan yang sudah selesai.

5. Setelah kayu terpotong sesuai dengan ukuran yang telah ditentukan, gosok kayu dengan kertas pasir agar lebih halus. 
6. Kemudian cat pola tersebut dengan cat minyak berdasarkan warna yang sudah menjadi ketentuan warna gorga tersebut.

7. Setelah semua telah dicat dengan sempurna, biarkan di bawah sinar matahari agar cat cepat mengering.

8. Setelah cat mongering, kemudian semprot dengan cat pengkilap kayu dan keringkan lagi di bawah sinar matahari.

9. Hiasan dinding dari motif ornamen gorga siap untuk dipasang kedinding untuk menambah indah dinding rumah anda.

\section{Proses Pembuatan Hiasan Dinding}
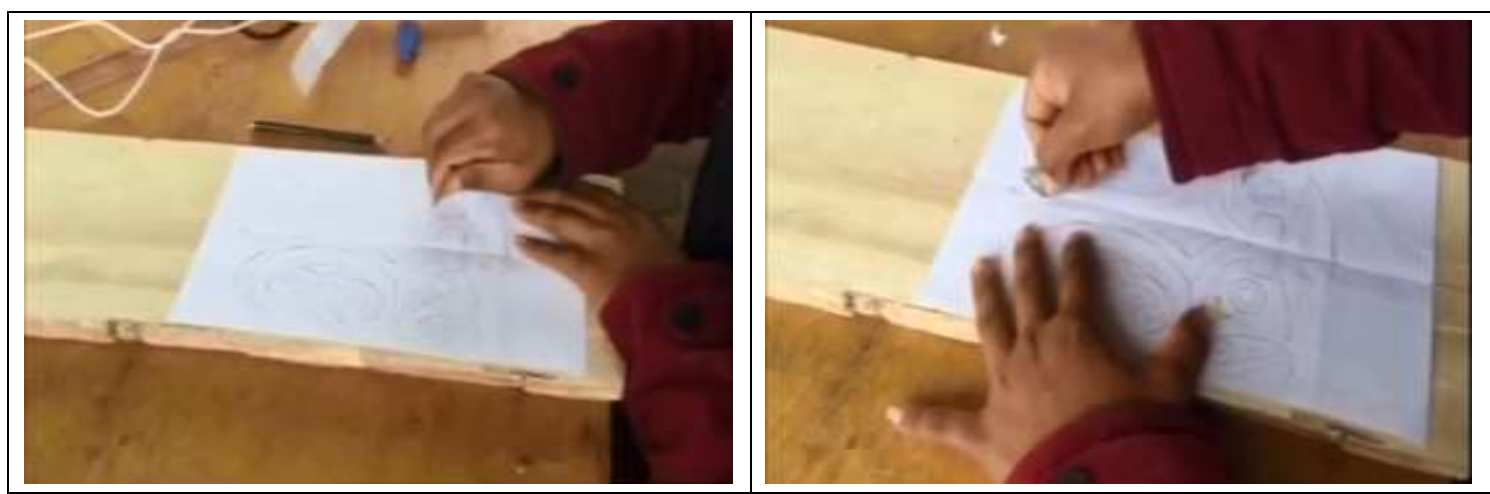

Gambar 1 : Proses Pembuatan Pola Di Atas Kertas
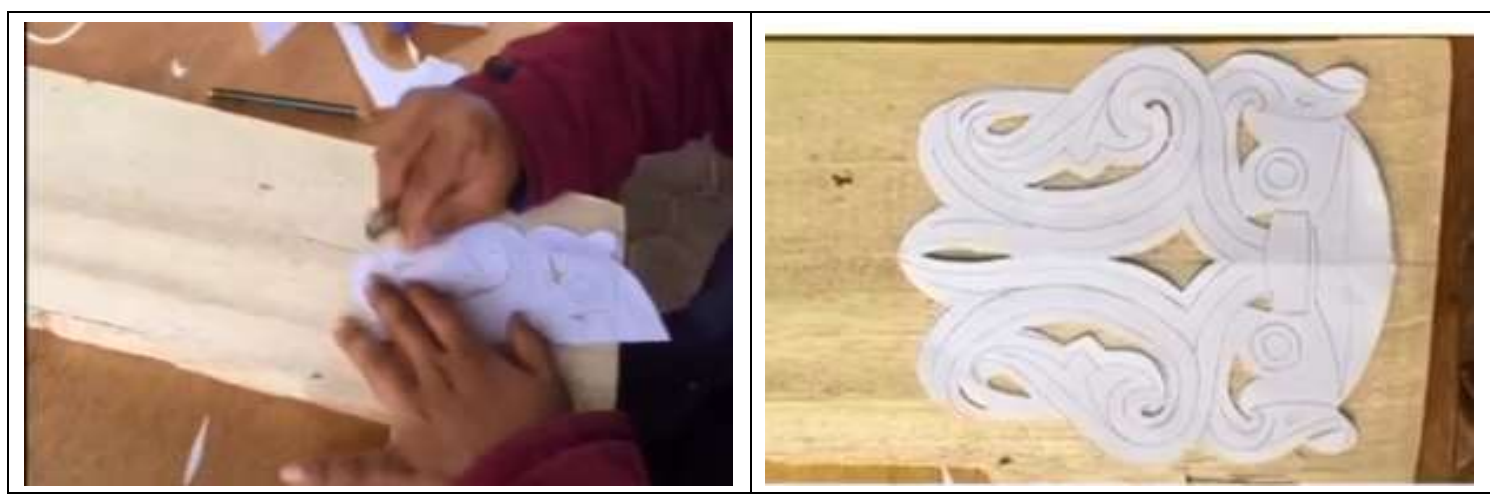

Gambar 2 : Proses Pemotongan Kertas Mengikuti Pola Yang Sudah Jadi
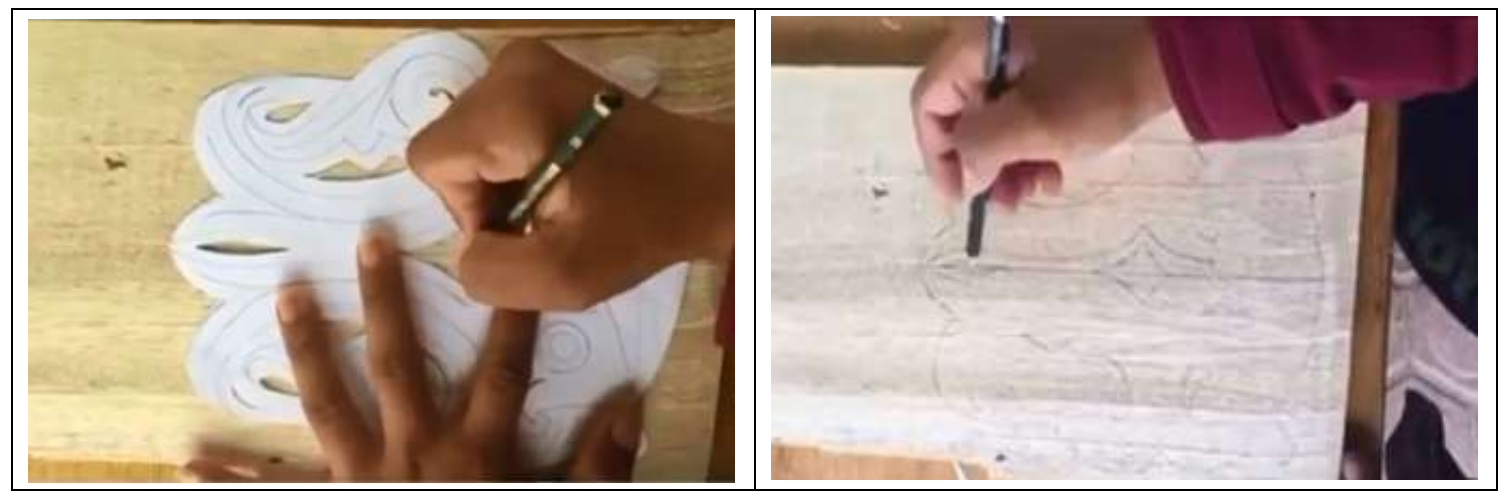

Gambar 3 : Proses Pembuatan Pola Di Atas Kayu 


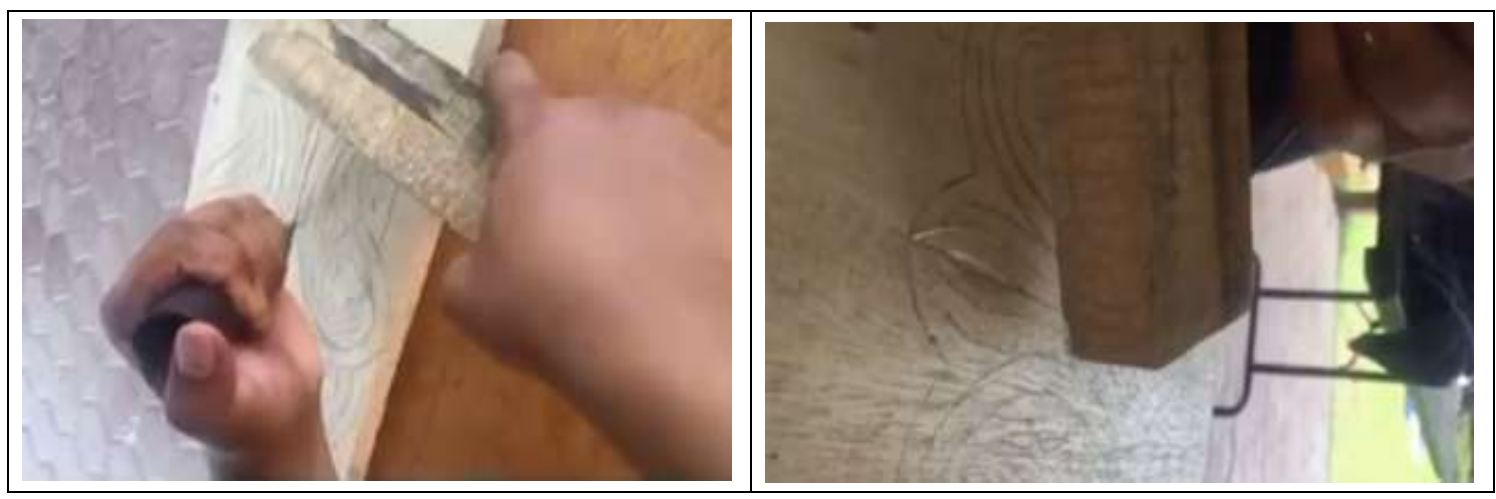

Gambar 4.4 : Proses Pemahatan Pola

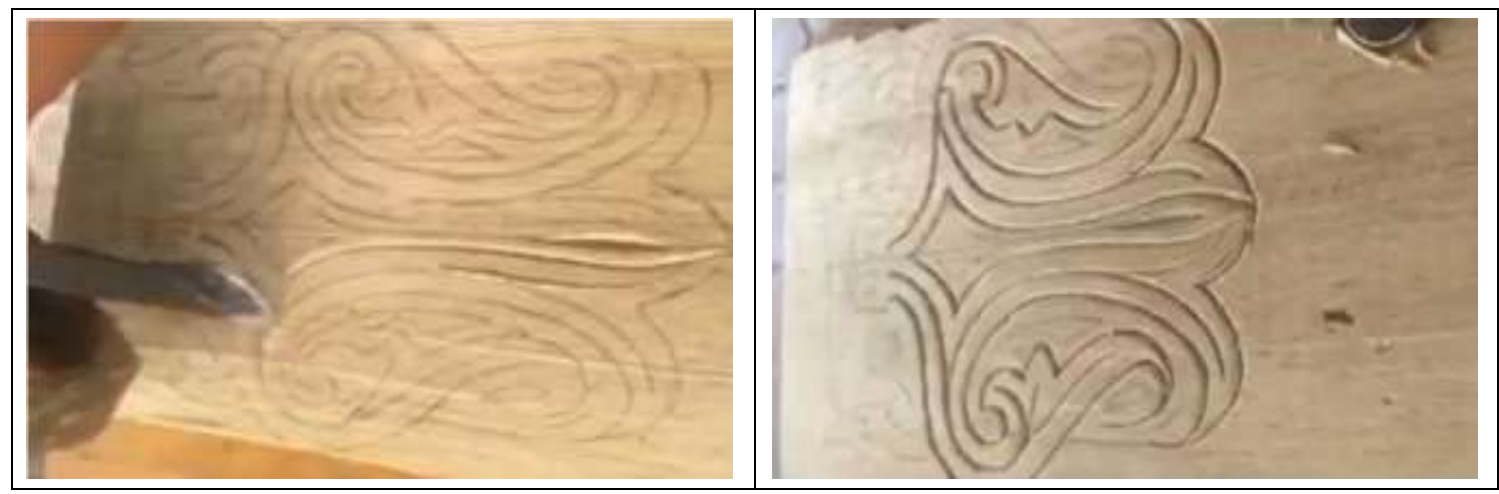

Gambar 4.5 : Hasil Pahatan Yang Sudah Selesai
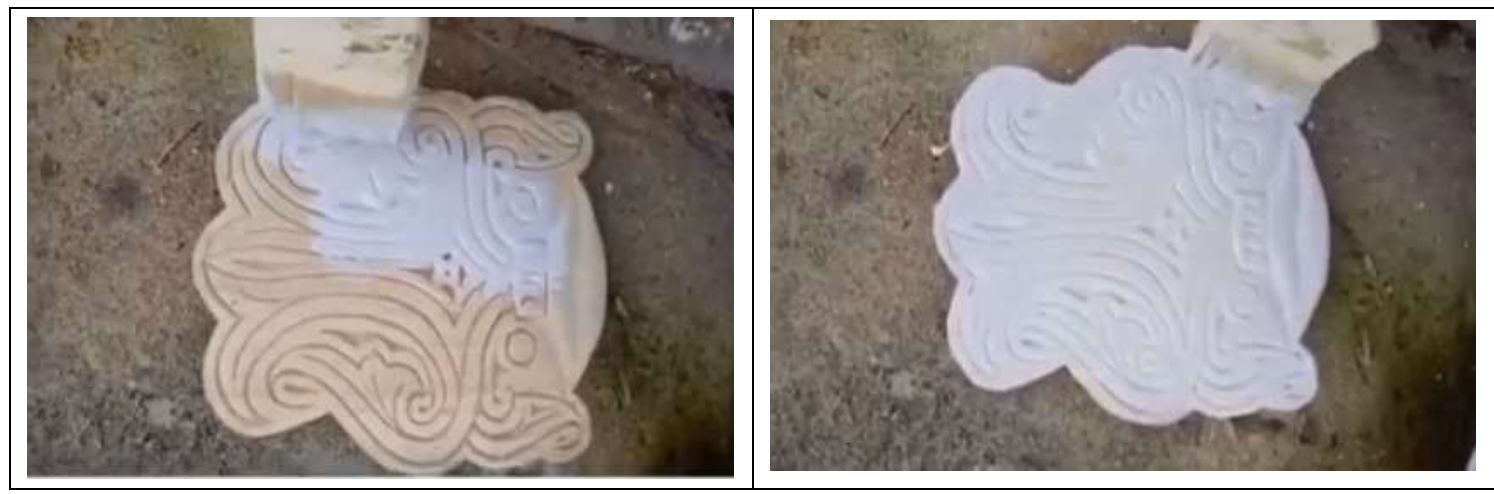

Gambar 4.6 : Proses Pengecatan Warna Dasar Putih

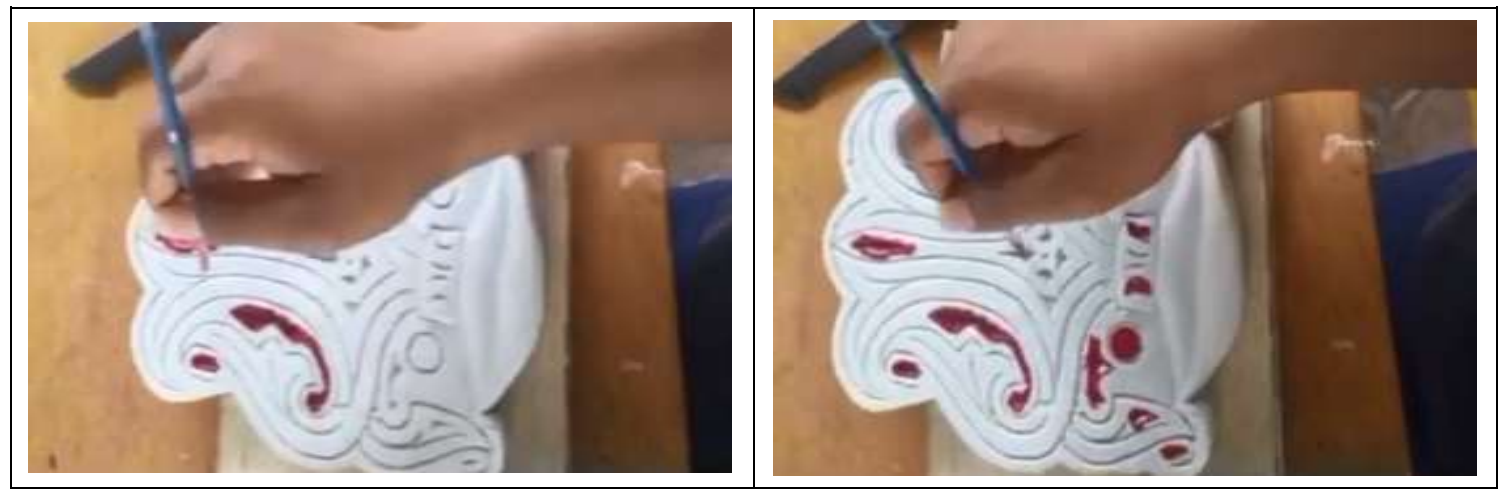

Gambar 4.7 : Proses Pengecatan Warna Merah 


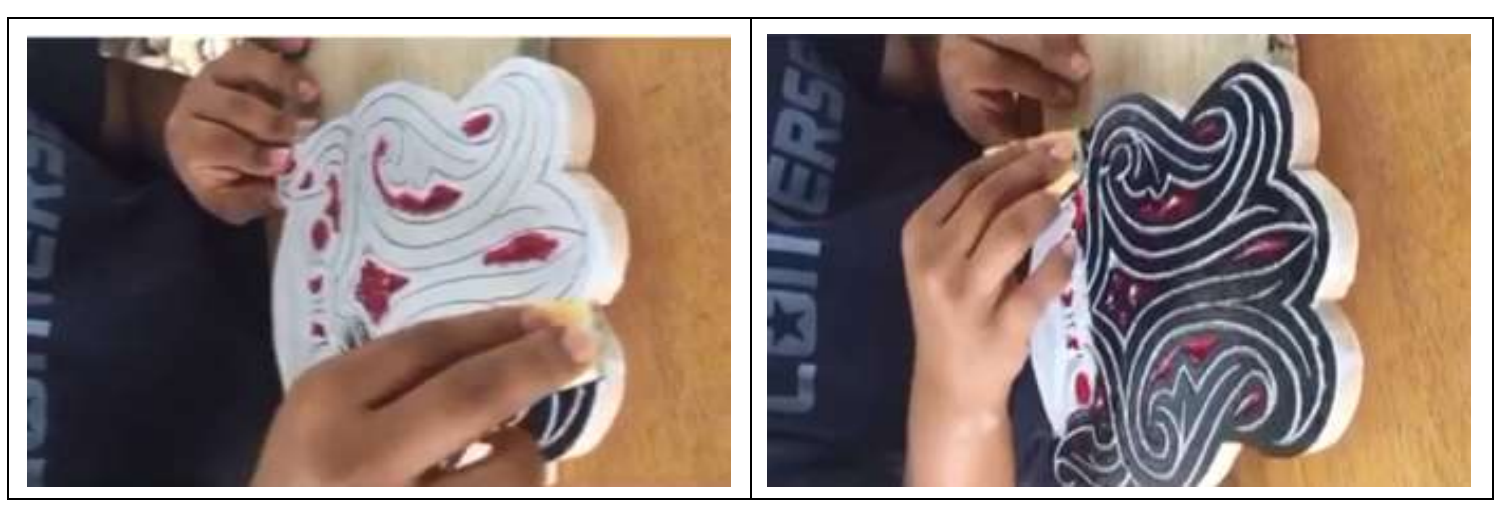

\section{Gambar 4.8 : Proses Pengecatan Warna Hitam}

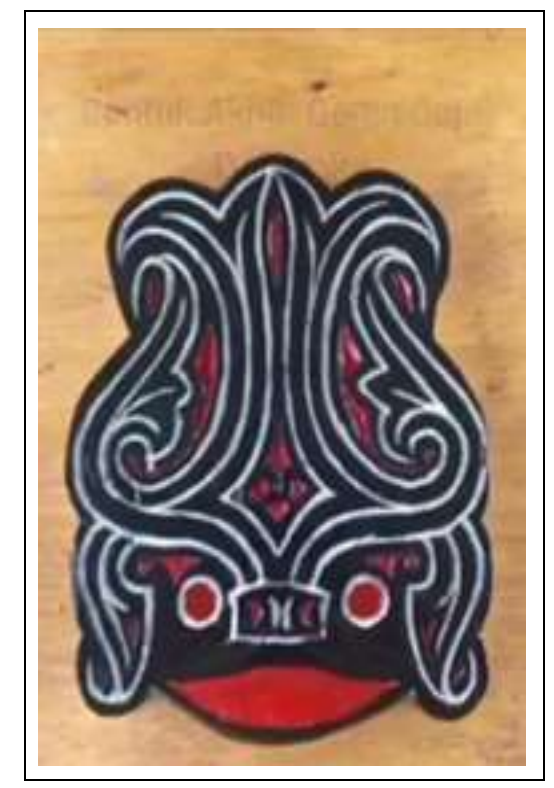

\section{Gambar 4.9 : Hasil Hiasan Dinding}

\section{KESIMPULAN}

Dengan perkembangan zaman tentang banyaknya variasi tentang hiasan dinding. Maka kebutuhan dari hiasan dinding untuk mempercantik rumah semakin bertambah. Dengan bertambahnya kebutuhan hiasan dinding, maka kita di tuntun untuk berfikir kreatif untuk menciptakan bermacam bentuk karya seni yang dapat digunakan sebagai hiasan dinding. Dengan berkembangnya hiasan dinding para pengerajin mulai mamanfaatkan motif ornamen gorga sebagai inpirasi pembuatan hiasan dinding.

Hiasan dinding ornamen Gorga dibuat dengan menggunakan bahan kayu. Hiasan dinding motif gorga hanya memiliki tiga warna saja yaitu warna hitam, merah dan putih sebagai ciri khas warna ornamen Gorga. Warna hitam disebut Banua Toru yang diartikan alam bagian bawah atau dibawah tanah. Dalam kehidupan sehari-hari warna hitam sebagai simbol kekuatan pengobatan atau kedukunan. warna merah disebut banua tongah yang artinya kosmos bagian tengah, permukaan bumi tempat manusia, binatangbinatang, dan tumbuh-tumbuhan hidup. Maka warna merah melambangkan keberanian dan kesaktian. warna putih disebut banua ginjang diartikan kosmos bagian atas, langit, tempat 
bersemayam para dewa. Bagi masyarakat batak warna putih melambangkan ketulusan dan kejujuran yang berbuah kesucian. Maka dari itu hiasan dinding dari motif gorga memiliki warna yang sama dengan warna aslinya.

\section{DAFTAR PUSTAKA}

[1] Apriadi, Ilham. (2015). Efektivitas Metode Latihan Dalam Membuat Keterampilan Hiasan Dinding Paper Quilling Bagi Anak Autis. Padang: E-JUPEKhu (Jurnal Ilmiah Khusus Volume 4 Nomor 3 September 2015

[2] Chressetianto, Ayhwien. (2013). Pengaruh Aksesoris Dan Elemen Pembentuk Ruang Terhadap Suasana Dan Karakter Interior Lobi Hotel Artotel Surabaya. Jurnal INTRA Vol. 1, No. 1, (2013) 1-7

[3] Gultom, Ruhut. (2015). Penerapan Ornamen Batak Toba Pada Bangunan Bale Parsantian Parmalim Di Jalan Air Bersih Medan. Tugas Akhir.

[4] Gustami, SP. Perkembangan Mutakhir Seni Kriya di Yogyakarta,"Jurnal Seni Pengetahuan dan Penciptaan Seni (Yogyakarta: STSRI “ASRI”, XVIII Januari 1984).

[5] Juliana, Netty. (2015). Kriya Hiasan Dinding Gorga Desa Naualu. Medan: Jurnal Pengabdian Kepada Masyarakat Vol 21, No. 81, (2015)

[6] Panto Siburian, Tulus. (2017). Makna Simbolik Ornamen Gorga Budaya Batak Toba. Tugas Akhir.

[7] Suharto, Ambarwati, Dwi Retno Sri. (2016). Pemanfaatan Kelapa (Batang, Tapas, Lidi, Mancung, Sabut, Dan Tempurung) Sebagai Bahan Baku Kerajinan. Yogyakarta: Jurnal Humaniora_Hibah.

[8] Sutarman, I Wayan. (2015). Pemanfaatan Limbah Industri Pengolahan Kayu Di Kota Denpasar ( Studi Kasus Pada CV Aditya). Jurnal PASTI Volume X No. 1, 15-22

[9] Hermawan, Susanto. (2015). Pemanfaatan Limbah Kayu Sebagai Bahan Penciptaan Jam Lampu Dinding Dengan Motif Hias Klasik Jawa Dan Bali. Universitas Negeri Yogyakarta.

[10] https://id.wikipedia.org/wiki/Gorga_Batak_Toba Diakses Pada Tanggal 25 Februari 2020 . 